2004

\title{
Cluster-based economic strategy, facilitation policy and the market process
}

article version: accepted manuscript

Desrochers, Pierre

Sautet, Frédéric

Desrochers, Pierre, and Frédéric Sautet. "Cluster-based economic strategy, facilitation policy and the market process." The Review of Austrian Economics 17.2 (2004): 233-245.

The final publication is available at Springer via

https://link.springer.com/article/10.1023/B:RAEC.0000026833.26220.2d

\section{HOW TO CITE TSPACE ITEMS}

Always cite the published version, so the author(s) will receive recognition through services that track citation counts, e.g. Scopus. If you need to cite the page number of the TSpace version (original manuscript or accepted manuscript) because you cannot access the published version, then cite the TSpace version in addition to the published version using the permanent URI (handle) found on the record page. 


\section{Cluster-Based Economic Strategy, Facilitation Policy and the Market Process}

Pierre Desrochers, Montreal Economic Institute

Frédéric Sautet, New Zealand Treasury

\section{Introduction}

The geographical concentration of related manufacturing and service firms is as old as economic development, ${ }^{1}$ but it has drawn renewed attention in the last two decades in the wake of the spectacular growth of regional economies such as Silicon Valley (South San Francisco Bay), Route 128 (greater Boston area) and the « discovery » of numerous other manufacturing districts from Denmark and Italy to Thailand and Japan. ${ }^{2}$

While numerous policy prescriptions for regional growth that built on related and interdependent firms have been devised, ${ }^{3}$ the most appealing - in political if not economic terms - has been the "cluster" based economic development strategy put forward by Harvard Business School's Michael Porter. The literature on clusters has literally exploded since the mid-1990s with the publication of many "how to" books and the organization of several dozen major conferences on the topic. Many major economic consulting firms and university research groups have also been created to study and developed ways to implement this strategy (Waits 2000). As one observer has put it, "governments and regional development organizations on all continents except Antarctica have come calling" to Porter (Hoffman 2001).

In essence, Porter's analysis/strategy rests on the idea that the geographical concentration of companies working within in a particular field produces a "competitive advantage" for these firms. Clusters, it is argued, raise the productivity, innovativeness, competitiveness, profitability and job creation of their constituent firms, of the geographical areas in which they are located, and thence of the wider economy. Originally framed by Porter in his 1990 best-seller The Competitive Advantage of Nations (Porter 1990), his prescription was further repeated, refined and sometimes made more confusing in later years (Porter, 1998; 2000a; 2000b). Although the Harvard scholar did not invent or even do the most

\footnotetext{
For example, Alfred Marshall refers to an essay published on the various industrial districts of England that was published in the 13th century (Marshall 1986 [1920]:223).

2 In the USA, for instance, one may find: Boston Route 128; Silicon Alley (NYC's financial, advertising and multimedia districts); Detroit (car industry); Minneapolis (medical equipment) and Silicon Valley (computers). In Italy, one may find: Sassuolo (ceramic tiles); Carpi (woodworking machinery); Montebelluna (ski industry) and Milan (fashion industry). In France, one may find: Limoge (porcelain); Grenoble (engineering and ski industries); Marseille (soap industry), Paris (fashion industry) and Grasse (perfume industry). In Germany, one may find: Soligen (cutlery); Remscheid (tool-making industry); Nuremberg (pen and pencils industry); Velbert (locksmith wares); Stuttgart (car industry) and Pforzheim (jewelry industry).

${ }^{3}$ Lagendijk and Cornford (2000) have highlighted the growth of a "regional development industry" that is oriented towards the production and circulation of knowledge in the form of reports, conferences and seminars.
} 
original work on regional economic development, his reputation and well-established status as one of the world's foremost business strategy theorist put him in a unique position to popularize his economic development prescription to policy-makers worldwide. ${ }^{4}$

Upon closer examination, however, one must face the facts that not much is new about this strategy and that it probably contains the seeds of its own demise. As will be argued in what follows, the concept is fuzzy and its promotion of regional specialization at the expense of spontaneously evolved diversity makes regions more likely to experience economic downturns, prevents the spontaneous creation of inter-industry linkages and hampers the creation of new ideas and businesses.

\section{Michael Porter's Cluster-Based Economic Strategy Development: An Overview $^{5}$}

\subsection{The essence of clusters}

In Porter's views, clusters are made up of firms that are linked in some ways and that are geographically proximate. More precisely, clusters are geographic concentrations of interconnected companies, specialized suppliers, service providers, firms in related industries, and associated institutions such as universities, standards agencies and trade associations in a particular field that compete and/or cooperate with each other. The fact that these firms and institutions are geographically proximate facilitates the movement of ideas and people between them, which ultimately promotes innovative behavior.

Porter's view of clusters, however, is said to be more inclusive than the older notion of "industrial district" developed by Alfred Marshall (1920) at the turn of the $20^{\text {th }}$ century. While Marshall focused on very similar firms, Porter's clusters are not limited to single industries, but encompass an array of linked industries and other entities important to competition. They therefore often extend downstream to channels or customers and laterally to manufacturers of complementary products or companies related by skills, technologies, or common inputs. Furthermore, in Porter's framework, this geographic scope can range from a region, a state, or even a single city to span nearby or neighboring countries: "The geographic scope of a cluster relates to the distance over which informational, transactional, incentive, and other efficiencies occur" (Porter 2000a: 16).

Considering the extent to which all industries ultimately depend on each other, however, it is no surprise that the boundaries of any given clusters are often in the eyes of the beholder. As Porter (2000a: 17) puts it: "Drawing cluster boundaries often is a matter of degree and involves a creative process informed by understanding the linkages and

\footnotetext{
${ }^{4}$ See Capello (2002) and Desrochers $(1998 ; 2000)$ for a list of books and articles that survey older contributions to the topic.

${ }^{5}$ For a more detailed introduction to this issue, see, among others, the special issue of Economic Development Quarterly, 14 (1), February 2000; Bergman and Feser (1999); and Martin and Sunley (2003).
} 
complementarities across industries and institutions that are most important to competition in a particular field." Similarly, cluster boundaries "rarely conform to standard industrial classification systems, which fail to capture many important actors in competition and linkages across industries" (p. 18). As a result, because parts of a cluster often are put into different traditional industrial or service categories, significant clusters might be obscured or even unrecognized. For example, Porter (2000b: 255) points out that Massachusetts firms involved in the production of medical devices were "buried within several larger and overlapping industry categories, such as electronic equipment and plastic products."

While Porter's theory was initially associated with a strong emphasis on competition, it is now closer to the work of earlier authors on "flexible production" that emphasized the cooperative nature of the relationship between related and geographically proximate firm (Harrison, 1992). As Porter now writes, clusters represent "a combination of competition and cooperation. Vigorous competition occurs in winning customers and retaining them. Because of the presence of multiple rivals and strong incentives, the intensity of competition among clusters often is accentuated. Yet cooperation must occur in a variety of areas, much of it vertical (buyer-supplier), with related industries, and with local institutions." (p. 25). Competition and cooperation can therefore coexist because they occur on different dimensions or because cooperation at some levels is part of winning the competition at other levels.

\subsection{Governmental role in cluster formation and support}

While Porter acknowledges that "most clusters form independently of government and sometimes in spite of it" (p. 26), he nonetheless provides ample justification for policy interventions. But while government should reinforce and build on established and emerging clusters, they should avoid the temptation to create entirely new ones because "there should be some seeds of a cluster that have passed a market test before cluster development efforts are justified" (p.26).

How should government promote cluster's growth? In essence, by removing barriers to innovation, investing in basic human and capital infrastructure, and supporting the geographical concentration of related firms. As he put it: "The process of cluster upgrading involves recognition that a cluster is present and then removing obstacles, relaxing constraints, and eliminating inefficiencies that impede productivity and innovation in the cluster. Constraints include human resources, infrastructure, and regulatory constraints" (p. 26). While some of these problems can be addressed to varying degrees by private initiatives, others can, in his opinion, only be dealt with by the government. For example, government regulations might create unnecessary inefficiencies, infrastructure might be lacking and education and training policies might overlook cluster needs.

The key to Porter's strategy, however, is to facilitate the geographical concentration of related and mutually supportive firms. By doing so, policy makers avoid the problems 
associated with the support of individual firms (which distorts market signals), industries (which presumes that some industries are better than others and distorts market signals) and sectors (which are too broad to be competitively significant). As Porter puts it:

A cluster focus highlights the externalities, linkages, spillovers, and supporting institutions so important to modern competition. By grouping together firms, suppliers, related industries, service providers, and institutions, government initiatives and investments address problems common to many firms and industries without threatening competition. A government role in cluster upgrading, then, will encourage the building of public or quasi-public goods that significantly affect many linked businesses. Government investments focused on improving the business environment in clusters, other things being equal, might well earn a higher return than those aimed at individual firms or industries or at the broad economy (p. 27).

While Porter's prescription might be reminiscent of past failed attempts by policy makers to "pick winners", he argues that "a role for government cluster development and upgrading should not be confused with the notion of industrial policy" and that "the intellectual foundations of cluster theory and industrial policy are fundamentally different, as are their implications for government policy" (p. 27). According to Porter, industrial policy rests on a view of competition in which some industries offer greater wealth-creating prospects than others and are therefore targeted for support. Industrial policy also tends to centralize intervention decision at the national level. Cluster theory, on the other side, "rests on a broader and dynamic view of competition among firms and locations, based on the growth of productivity. Interconnections and spillovers within a cluster often are more important to productivity growth than is the scale of individual firms" (p. 27). As a result, instead of targeting specific clusters, all existing and emerging clusters deserve attention.

While clusters have been all the rage, they are problematic on many counts.

\section{Issues to Consider with Socially Engineered Clusters}

\subsection{The fuzziness of cluster boundaries}

While Porter originated the term "cluster", it has become commonly used in a variety of ways by a wide array of academics, consultants and policy makers. At one extreme, the term refers to national groups of industries and firms that are strongly linked, but dispersed over several different locations within a country. At the other, "clusters" are identified as local groupings of similar firms in related industries within a highly spatially circumscribed area. In between, clusters have come to encompass such industries as the K-12 Minnesota public school system (Rosenfeld 2001)!

The problem, as Martin and Sunley (2003) point out in their magisterial survey of current policy prescriptions, is that clusters are constructs with essentially no self-defining boundaries, whether in terms of inter-sectoral, inter-firm linkages, information networks and geographical reach. It is therefore not surprising that clusters have often been viewed 
through political lenses. As Norton (1999, non-paginated) put it: "To skeptics, cluster theory sometimes looks like a vehicle for state and local government officials in search of a targeting rationale." As Martin and Sunley (2003) further add, most cluster policies do not identify working clusters, but rely instead on more immediately and statistically visible industrial sectors. In practical terms, policy makers are typically under pressure to find clusters in as many regions as possible for fear of offending some regional interests. The result is that while Porter's clusters are theoretically not supposed to be economically specialized entities in the "industrial district" sense, in practice virtually all identified clusters worldwide are very narrowly so.

Practical considerations also help explain the inherent "fuzziness" of cluster boundaries. The first is that if the concentrations of related firms has always been a spontaneous results of market processes, ${ }^{6}$ the different capital requirements of various industries have always resulted in widely different geographical scales, ranging from to the street level. Secondly, cities are the result of a unique human trait, the propensity, as Adam Smith (1776 [1976], 25) famously wrote, to "truck, barter and exchange one thing for another" which in turn leads to an ever increasing and geographically dispersed division of labour. As a result of genus Homo's propensity to exchange, cities have never been predominantly closed or self-sufficient systems, but rather nexus of trade where individuals belonging to various firms and networks interact in different ways and on different geographical scales. The result is that even in highly advanced regional economies such as Silicon Valley and Route 128, outside buyers and suppliers are typically deemed more important by local firms than their surrounding neighbours (Desrochers 2000).

Finally, industrial classification schemes are themselves highly problematic. Indeed, as the economic Zvi Griliches (1990) once put it, they may be nothing more than a mirage. Among other problems is the fact that industrial classifications hide the multi-product nature of many firms and the very different expertise of their employees. Furthermore, their boundaries are typically arbitrary. For example, the old American Standard Industrial Classification System used both "product" and "production process" criteria to delineate various categories, while ignoring as distinct categories important industries such as plastics and electronics (Desrochers 2001a).

\subsection{In practice, clusters ARE about "picking winners"}

Porter takes pains to differentiate cluster strategy, which is based on dynamic improvement, from industrial policy where politicians "pick the winners" based on a host of criteria that are typically more political than economic. As one commentator has put it, Porter's wording "will strike some readers as a fine distinction," but in practice cluster strategy really do amount to picking winners (Norton 1999, non-paginated). Besides,

\footnotetext{
${ }^{6}$ Traditionally, economists and geographers have explained this phenomenon by the existence of external economies such as the shared fixed costs of common resources (especially in terms of a pool of skilled workers), low information costs, the development of specialized inputs and services for the local market, low transportation costs, low agency costs in terms of financing (firms in clusters often obtain financing from local banks or venture capitalists who closely monitor their investments) and new business start-ups, and technological spillovers (close proximity allows firms' employees to resolve their problems more cheaply and easily while giving them the opportunity to learn sooner and more directly about new and innovative technologies and practices).
} 
despite all the hype, in practice clusters do not constitute a radical break from past practices. Indeed, as Rosenfeld (2001) has argued, what has typically happened is that many local development officials have backed into cluster initiatives from pre-existing network support and other programs.

Unfortunately for cluster proponents, targeted local industrial strategies have been widely used for several decades and have a long and unsuccessful history (Buss 1999, Hansen 1995). For example, Buss (1999: 343) argues that typically "targeted industry studies use poor or inappropriate data, deeply flawed social science methods, and simplistic mathematical models in producing targets. Targets themselves tend to be dubious." As Buss sees it, targeting strategies, including cluster-based targeting, are not practiced because of their scientific merit, but because they appeal to certain political constituencies. Impressive analytics can be drummed up on demand to justify inherently political proposals and, because they have the appearance of scientific backing, quickly generate a "herd effect" among policy advisers. Once some states and localities develop targeting strategies, others feel compelled to follow suit.

Apart from purely political reasons, economic theory and past experience teach us that policy-makers are not in a better position than market actors to "pick" winners. Among other problems, governments officials typically have little understanding of technological discovery processes and are too removed from the workplace to identify real opportunity areas. As Miller and Côté (1985) explain, government programs assume that innovation results from a chain that starts with research, proceeds to the development of new products, and leads to their market introduction. As a result, this approach attributes a central role to technological push at the expense of market pull and often leads to technologies in search of markets. Actually, in most cases technological innovation has nothing to do with scientific research, or, to be more specific, scientific research is almost never at the origin of innovation, it is rather the result of it (Rosenberg 1982, Kealey 1997). As Schmookler (1966: 199) argued, almost all instances of innovation that he studied were not stimulated by scientific research but by the realization that a costly problem had to be solved or that a profit opportunity could be seized. According to Miller and Côté, this is one of the main reasons why "innovation centers" and other greenhouses in innovation parks opened in the USA and Canada in the 1970s and 1980s have all failed without exception. ${ }^{7}$

A main reason for the persistence of geographical agglomeration has a lot to do with the generation and transmission of tacit knowledge that is related to the "particular circumstances of time and place" (Hayek 1948). In an industry, the crucial knowledge is not so much the knowledge that is explicit, formalized and that can be easily

7 Using econometrics, Richard Shearmur and David Doloreux (2000) have studied the influence of science parks in the Canadian context and couldn't find any significant results. As they put it: "Science parks do not appear to have any distinguishable effect upon industrial structure, and in particular they have no discernible effect upon high-tech employment - whether in the manufacturing or in the service sectors". Thus one may doubt whether science parks have the influence that (local) governments pretend they can have on the development of regions and agglomeration. "The question which remains open is the extent to which any planned intervention can create the dynamics necessary for these [agglomeration] economies to appear: despite their ambition, there is no evidence that Canadian science parks are a significant contributing factor. Rather, they tend to emerge in cities which are already predisposed to higher concentrations of high-tech industries" (Shearmur and Doloreux 2000: 1078-9). See also Massey et al (1992) and Ferguson (1995), which come to similar conclusions. 
communicated, it is the knowledge that is not standardized, is embodied in human capital and acquired through experience. It is the knowledge that can only be bought and sold through the transfer of individuals and can hardly be specified. It is the sum of experience that firms buy when they hire individuals who have "been around" for a long time. It is the knowledge that only individuals who have been working in the same industry or firm for a certain amount of time possess. One cannot predict in advance which bit of knowledge will be used, as the circumstances under which this is realized cannot be determined, they depend on the time and place. ${ }^{8}$

Furthermore, as Macdonald (1992) argued, government officials are not well placed to deal with the flows of tacit knowledge that make the richness of prosperous regional economies. In most cases, policy won't even touch the real issues such as the knowledge of the reality of the current marketplace as it is perceived, as well as knowledge about a potential future state of the market. ${ }^{9}$ Innovation is about turning information into knowledge and what matters here is the connection between personal knowledge and reality. While it is true that physical proximity often plays an important role in this process, Hansen (1995: 6) observes that past experience teaches us that "the clustering of firms in a given area does not by itself create decentralized processes of collective learning and continual innovation" and that the patterns of geographic change are too complex to be entirely explained. The birth, life and death of clusters and industrial districts are part of a spontaneous order that rests on entrepreneurial discovery and the generation of explicit and tacit knowledge.

Clusters of firms are important to economic development and performance. However, one must realize that they will form spontaneously and that the role of (local) tacit knowledge in their development is fundamental. This means that predicting which sectors are going to produce clusters of firms in the future is not possible. Clustering is the result of entrepreneurial activity and is driven by the production of valued goods to seize profits. Governments cannot therefore supersede the market in the creation of clusters.

\subsection{The importance of local diversity}

While regional specialization has long been thought by economists to be both the logical outcome of market competition and the best geographical setting for innovation, this perspective has been challenged on several counts.

\section{Static externalities and regional employment stability}

In addition to "localization economies" which explains the grouping of firms working in a similar line of business, one also finds "urbanization economies" where various activities that do not seem to be related benefit from the close spatial proximity of each other by allowing, for example, the profitable operation of ports and airports.

8 See also Maskell and Malmberg (1999) on the issue of tacit knowledge and interactive learning amongst firms.

9 As Macdonald (1992: 54) puts it: "The programmes by which government policy is implemented tend to be concerned with formal information flow through institutional channels; it is difficult to devise a formal programme for informal information flow. Put crudely, governments may promote conferences and the presentation of conference papers from which relatively little information flows, but they would be reluctant to subsidise the beer to stimulate the conversations at the bar in which a great deal of information flows. Governments are generally ill at ease with information programmes anyway, preferring to deal with the tangible, and to treat information almost as if it were a tangible good." 
Urbanization economies are also in a sense akin to the economies that the division of labor in the market provide in allowing any individual or firm to obtain from outsourcing a function that is done more effectively by someone specialized in it. For example, law, accounting and software engineering firms can serve a whole different array of customers in an area better and/or more cheaply than if these firms were maintaining these functions within their corporate structure.

An added benefit of diversified local economies is the fact that they are more stable than highly specialized regions that are more prone to abrupt decline if their main line of business is supplanted by competitors located elsewhere or if new and better substitute products are manufactured elsewhere. Indeed, the economic landscape is littered with local areas of industrial specialization that were once prosperous and dynamic but have since gone into relative or absolute decline. Confronted with this fact, local economic development policy has long been concerned with the promotion of a more diversified economic base for declining regions (Siegel et al. 1995). As Rosenfeld (2001: 2) points out: "Michael Porter's Competitive Advantage of Nations (1990) challenged the prevalent U.S. local development objective of very diversified economies". It is not clear to us that this shift is beneficial for the future of regional economies. ${ }^{10}$

\section{Industrial Symbiosis}

Another policy prescription that has reached a worldwide audience in recent years, although not to the same extent as "clusters," is the idea of planning "eco-industrial parks" (EIPs). The policy rationale behind EIPs is to co-locate very different firms that will feed on each other's waste, in the process turning them into useful inputs. This idea first emerged following the "discovery" of such a spontaneously evolved phenomenon in the small Danish industrial town of Kalundborg. In short, in Kalundborg a power company supplies residual steam from its coal-fired power plant to an oil refinery and in exchange receives refinery gas that was formerly flared as waste. The power plant burns the refinery gas to generate electricity and steam and sends its excess steam to a fish farm, to a district heating system serving 3,500 homes and to a pharmaceutical and enzyme manufacturing plant. Sludge from the fish farm and pharmaceutical processes becomes fertilizer for nearby farms. Surplus yeast from the biotechnology plant's production of insulin is shipped to farmers for pig food. The fly ash from the power plant is sent to a cement company, while gypsum produced by the power plant's desulphurisation process goes to a gypsum wallboard company. Finally, the refinery removes sulphur from its natural gas and sells it to a sulphuric acid manufacturer. Similar spontaneous, although less formalized, patterns have also been observed in the Austrian province of Styria, the Ruhr region of Germany, the Jyväskylä region of Finland, the Houston Ship Channel, and the ARCO refinery in Los Angeles. Despite claims to the contrary, however, such "industrial symbiosis" has always been a widespread phenomenon and is unlikely to be improved by public planning (Desrochers 2001b; 2002).

10

An interesting case is the debate that has taken place in New Zealand in the past two years, where government-led cluster and sector specialisation is seen as a way to promote growth in a small and distant economy. However, the argument of size and distance is not sufficient to see socially engineered competitive advantage as a solution to a potential lack of growth (see Sautet 2002a). 
With "cluster" led development becoming increasingly prominent, the task of promoting industrial symbiosis, which requires local diversity, has proven difficult in many settings. As one Asian academic involved in the development of EIPs observed: "In fact, tenants belonging to the same industry are put in the same zone inside the estate. Freedom of choice is also constrained: Many investors cannot pick the location they prefer, but similarly many estate managers claim that they cannot select the right industry mix" (Chiu 2002).

\section{Local diversity and knowledge combination}

Urban theorist Jane Jacobs $(1961,1969)$ has long argued that the raison d'être of cities and what makes their wealth is precisely the diversity that one may find there. One of her insights that has finally attracted the attention of economists in recent years is that urban development and growth stems in large parts from the possibility that individuals are given to experiment with different sources of knowledge, encounter individuals with different experiences and background. This is why Jacobs described the process of innovation taking place in urbanization economies as almost always cutting across conventional classification systems. "The point is that when new work is added to older work," she writes, "the addition often cuts ruthlessly across categories of work, no matter how one may analyze the categories" (Jacobs 1969: 62).

Some recent empirical studies that have attempted to test Jacobs' hypothesis have indeed come to the conclusion that cities that have a very diversified industrial structure create more growth and jobs than those that are more specialized (Feldman 2000). As Duranton and Puga (2000: 53) write: "The link between innovation and diversity seems fairly robust, so that highly innovative clusters cannot be bred in previously specialized environments." However, these analyses of Jacobs' hypothesis have remained at a fairly abstract level and have not dealt with the processes by which knowledge is actually created and exchanged by individuals. A case can nonetheless be made that creative individuals combine existing things in a new way by building on their capacity of using their previous know-how and of observing and learning new things. New knowledge combinations in the industrial realm are therefore accomplished by multidisciplinary teams working within a firm; by employees adding to, or switching their product line; by individuals moving from one type of production to another; by individuals observing a product/process in another setting and incorporating to their main activity; and by individuals possessing different skills and working for different firms collaborating with each other (Desrochers 2001a).

If innovation is understood as the combination of previously unrelated things, it seems obvious that diversified cities will be more likely to generate innovation than specialized ones, even though, of course, specialists in one area often need to rely on the expertise of their colleagues. A good setting for innovation would then seem to be a diversified city made up of many specialized clusters - which is historically what most important cities have been. In a dynamic world, socially engineered regional specialization is ultimately self-defeating for it dries up the pool of potential ideas and skillful people on which 
innovators can draw upon to combine unrelated things. Porter himself seems to have caught on this rationale when he argues the following:

"Under certain circumstances, however, cluster participation can retard innovation. When a cluster shares a uniform approach to competing, a sort of groupthink often reinforces old behaviors, suppresses new ideas, and creates rigidities that prevent adoption of improvements. Clusters also might not support truly radical innovation, which tends to invalidate the existing pools of talent, information, suppliers, and infrastructure. In these circumstances, a cluster participant might be no worse off, in principle, than an isolated firms (because both can outsource), but the firm in an established cluster might suffer from greater barriers to perceiving the need to change and from inertia against severing past relationships that no longer contribute to competitive advantage." (Porter 2000a: 24)

\section{There is no role for governments in cluster development}

Kirzner has often emphasized the idea that the main peril of regulation is the stifling of the entrepreneurial discovery process. He sees four main reasons why this is the case: (a) regulator's ignorance of the counter factual, (b) in the absence of profit motive (for regulators), the impossibility to discover opportunities for coordination improvements, (c) the potentially stifling impact of regulation on the discovery process and (d) the likelihood that government regulation may propel the market in a different direction, not necessarily desired by consumers (Kirzner 1979, Sautet 2002a).

By stifling the entrepreneurial process, regulation reduces the capacity of the market to generate knowledge that could otherwise improve the coordination of individuals' plans. In other words, the fundamental problem of regulation is that it reduces the coordinative properties of the market system.

As we emphasized above, policies that promote clustering often amount to picking-up winners. This is because governments cannot generate the knowledge that would be required to make most clusters work. There is no reason to think that under the institutional arrangements where governments take an active role in cluster promotion, the relevant knowledge will be generated. Thus even if governments were composed of individuals who had only the public welfare in mind, they would still not be able to implement successful cluster policies. The limits of governmental active policies are not so much in the nature of men, but in the knowledge that is required to implement these policies (Sautet 2002b).

This leaves us with another important issue. While one may acknowledge that governments are limited in their capacity to establish a successful industrial policy, one may still see a role for governments, which is to facilitate cluster emergence as opposed to design it. The issue of facilitation is not new in policy, but it has gained more prominence in recent times (e.g. the role of Industry New Zealand; Porter has promoted cluster facilitation in, for instance, his book Can Japan Compete?) Government facilitation is argued to be a core governmental role, akin to infrastructure development. 
We see facilitation as another variation on the theme of industrial policy. It is a way of promoting government intervention, while feigning to be non-interventionist. ${ }^{11}$ This is because at best facilitation is just a subsidy and therefore it is not useful (i.e. if it facilitates firms that would have succeed anyway, it is not required and if it facilitates firms that would have otherwise failed, it interferes with the selective process of the marketplace and subsidizes firms that should not have come into existence in the first place). At worst, facilitation amounts to picking winners as there is a limited amount of resources available at any given time and agencies that do the facilitating have to select which companies are being helped. Since there is no reason to think, as Kirzner argued, that governments face the incentives and possess the knowledge that would help them succeed in their selection process, there is no reason to think that facilitation is any different from other type of involvement in cluster development. In addition to this, one also has to consider public choice issues (especially regulatory capture by the agency that is supposed to do the facilitating). ${ }^{12}$

Finally, as we saw above, the idea that specialization is more desirable than a diverse environment is difficult to establish without any market test. It may be worth making a parallel between the work of Porter and the old Ricardian idea of specialization as used by social planners in the COMECON (where there would be a division of labor and specialization according to what planners had decided in Moscow). It is probably true that in many instances clusters of firms within greater diversified environments can be a source of productivity improvements, as they facilitate entrepreneurial discoveries. However, whether a particular instance has these properties is impossible to tell a priori and it is only through the trial and error process of the market that the best industrial structure emerges at one given point in time and space.

Fundamentally governments should make sure not to interfere with the coordinative properties of the market and not to limit the ways in which change is taking place. The life and death of cities, industries and regions is inevitable in a "living economy" (to use Mises's words), governments should not slow this process down.

\section{Conclusion}

Clusters development has become an important article in policy makers' and government advisers' toolboxes. Cluster-based economic development strategy regularly rises from boardroom tables and conference lecterns, cited as the solution to many economic ailments. Yet, upon closer examination, their rationale is often more political than rooted in a clear understanding of market processes.

\footnotetext{
${ }^{11}$ Porter et al. for instance explain: "Now government must work to improve the inputs available to business, facilitate competition, and encourage innovation. Improving the quality and dynamism of the business environment, not managing the competitive process, should be the government's new goal." (2000c: 158) Facilitation has become the new buzzword of policy, the new idea that will promote true economic performance and competition.

12

One should also add the idea that just like standard industrial policy is inconsistent with an open economy, the targeting that engineered clustering requires is probably also incompatible with an open economy (thanks to William $\mathrm{N}$. Butos for this remark). This is probably extremely relevant for small open economies such as New Zealand.
} 
Cluster facilitation is part of this "new vision" of policy where governments (supposedly) do not really play an intrusive role, but promote competitiveness, innovation and the quality of infrastructure. We argue that socially engineering clusters does not achieve the results that promoters of this view are seeking. This new vision of policy is just another variation on the old theme of industrial policy. Surely, promoters of free markets should rejoice, as the old view is not seen as a viable policy development anymore. However, one should be wary of the new alternative and understand its true nature.

We view socially engineered clusters as suffering from many drawbacks. For instance, the fact that clusters are widely understood to support regional specialization is problematic in light of the facts that regional specialization leaves regional economies more subjected to experience economic downturn, less likely to promote inter-firm linkages (including recycling linkages) and new technology combinations. Moreover, in practice, cluster development policy is about picking winners. Because governments do not face incentives nor have access to the knowledge that would make cluster development possible, we take the view that there is no active role for governments in cluster development.

Cluster facilitation is another instance of the constructivist myth and the "scientistic error" (to use Hayek's words) that promote social engineering as the fundamental nature of economic policy. The distinction between the institutional framework that defines the outer limits of the market and what one may deem "social engineering" is not always easy to make. We have argued in this paper that cluster facilitation policies and similar views on economic development are not part of the meta-strata that defines markets, but is truly an interference with consumers' preferences and thus is not desirable (if one is to achieve greater productivity and economic performance).

\section{References}

Bergman, E. M. and E. J. Feser. (1999) "Industrial and Regional Clusters: Concepts and Comparative Applications.” In: Jackson, R.W. (ed.) The Web Book of Regional Science Regional Research Institute, West Virginia University (http://www.rri.wvu.edu/WebBook/Bergman-Feser/contents.htm);

Buss, T. F. (1999) "The Case Against Targeted Industry Strategies." Economic Development Quarterly, 13 (4): 339-356.

Capello, R.. (2002) "Entrepreneurship and Spatial Externalities: Theory and Measurement." The Annals of Regional Science, 36(3): 387-402.

Chiu, A. S. (2002) "Ecology, Systems, and Networking. Walking the Talk in Asia." Journal of Industrial Ecology, 5(2): 6-8. 
Desrochers, P. (1998) “A Geographical Perspective on Austrian Economics.” Quarterly Journal of Austrian Economics, 1(2) : 63-83.

Desrochers, P. (2000) "Geographical Proximity and the Transmission of Tacit Knowledge." Review of Austrian Economics, 14(1): 25-46.

Desrochers, P. (2001a) "Local Diversity and the Processes of Dynamic Knowledge Externalities: Methodological Issues and Insights from the Study of Human Creativity." Growth and Change, 32(3): 369-394.

Desrochers, P. (2001b) "Cities and Industrial Symbiosis: Some Historical Perspective and Policy Implications.” Journal of Industrial Ecology, 5(4): 29-44.

Desrochers, P. (2002) "Regional Development and Inter-Industry Recycling Linkages: Some Historical Perspective." Entrepreneurship and Regional Development, 4(1): 49-65.

Duranton, G. and D. Puga (2000) "Diversity and Specialisation in Cities: Why, Where and When Does it Matter?" Urban Studies, 37(3): 533-555.

Feldman, M. (2000) « Location and Innovation: The New Economic Geography of Innovation, Spillovers and Agglomeration.” In: Clark, G.L., M.P. Feldman, and M.S. Gertler Oxford Handbook of Economic Geography, , pp. 373-394. Oxford: Oxford University Press.

Ferguson, R. (1995) Panacea or Let-Down? Science Parks in the Literature, The Small Business Research Group, Swedish University of Agricultural Sciences, August (http://www.ekon.slu.se/ richardf/scipklit/scipklit.html).

Griliches, Z. (1990) "Patent Statistics as Economic Indicator: A Survey". Journal of Economic Literature 28 (12): 1661-1707.

Harrison, B (1992). "Industrial Districts: Old Wine in New Bottles?" Regional Studies, 26(5): 469-483.

Hayek, F (1948) Individualism and Economic Order. Chicago: University of Chicago Press.

Hoffman, W. (2001) "Professor Porter Goes to Washington". The Doric Column, December 31 (http://mbbnet.umn.edu/doric/michaelporter.html)

Jacobs, J. (1961) The Death and Life of Great American Cities. New York: Random House.

Jacobs, J. (1969) The Economy of Cities. New York: Random House. 
Kealey, T. (1997) The Economic Laws of Scientific Research. New York: St Martin's Press.

Kirzner, I. M. (1979) “The Perils of Regulation: A Market-Process Approach” Reprinted in Kirzner, I. M. (1985) Discovery and the Capitalist Process. Chicago: University of Chicago Press.

Lagendijk, A. and J. Cornford (2000). "Regional Institutions and Knowledge - Tracking New Forms of Regional Development Policy." Geoforum, 31: 209-218.

Macdonald, S. (1992) "Formal Collaboration and Informal Information Flow." International Journal of TechnologyManagement, 7(1/2/3): 49-60.

Marshall, A. (1920) Principles of Economics, $8^{\text {th }}$ edition. London: MacMillan.

Martin, Rand P. Sunley (2003) "Deconstructing Clusters: Chaotic Concept or Policy Panacea?" Journal of Economic Geography, 3(1): 5-35.

Maskell, P. and A. Malmberg (1999) "Localised Learning and Industrial Competitiveness." Cambridge Journal of Economics, 23: 167-185.

Massey, D, P. Quintas and D. Wield (1992) High Tech Fantasies, Science Parks in Society, Science and Space. London: Routledge.

Miller, R. and M. Côté (1985). "Growing the Next Silicon Valley." Harvard Business Review, July/August: 114-123..

Norton, R. D. (1999) “Cluster Theories(1): Spatial Externalities.” In: Jackson, R. W. (ed.). The Web Book of Regional Science, Regional Research Institute, West Virginia University (http://www.rri.wvu.edu/WebBook/Norton/nortonupdate/neoflows1.htm).

Porter, M. (1990) The Competitive Advantage of Nations. London: Macmillan.

Porter, M. (1998) "Location, Clusters and the "New" Microeconomics of Competition." Business Economics, 33(1): 7-17.

Porter, M. (2000a) "Location, Competition, and Economic Development: Local Clusters in a Global Economy." Economic Development Quarterly, 14 (1): 15-34.

Porter, M. (2000b) "Location, Clusters and Company Strategy.” In: Clark, G. L., M. S. Gertler and M. P. Feldman (eds). The Oxford Handbook of Economic Geography, pp. 253-274.. New York: Oxford University Press.

Porter, M, H Takeuchi and M Sakakibara (2000c) Can Japan Compete? Cambridge, MA: Perseus Publishing. 
Rosenberg, N. (1982). Inside the Black Box: Technology and Economics. Cambridge: Cambridge University Press.

Rosenfeld, S. (2001) Backing into Clusters: Retrofitting Public Policies. Paper presented at the Integration Pressures: Lessons from Around the World, John F. Kennedy School Symposium, Harvard University, March 29-30 (http://www.rtsinc.org/publications/Harvard4\%20doc\%20copy.pdf)

Sautet, F (2002a) Economic Transformation, The Pretence of Knowledge and the Process of Entrepreneurial Competition. New Zealand Treasury Discussion Paper (http://www.treasury.govt.nz/et/\#9)

Sautet, F (2002b) "Kirznerian Economics: Some Policy Implications and Issues". Journal des Economistes et des Etudes Humaines, 1(12) : 131-51.

Schmookler, J. (1966). Invention and Growth. Cambridge: Harvard University Press.

Shearmur, R and D. Doloreux (2000) "Science Parks: Actors or Reactors? Canadian Science Parks in their Urban Context." Environment and Planning A, 32: 1065-1082.

Siegel, P. B., T. G. Johnson and J. Alwang (1995) "Regional Economic Diversity and Diversification: Seeking a Framework for Analysis." Growth and Change, 26(2): 261284.

Smith, A. 1776 (1976). An inquiry into the nature and causes of the wealth of nations. Oxford: Clarendon Press (General editors R. H. Campbell and A.S. Skinner. Textual editor W.B. Todd).

Waits, M. J. (2000) "The Added Value of the Industry Cluster Approach to Economic Analysis, Strategy Development, and Service Delivery." Economic Development Quarterly 14(1): 35-50. 